ISSN 1392-3196 / e-ISSN 2335-8947

Zemdirbyste-Agriculture, vol. 108, No. 4 (2021), p. 371-376

DOI 10.13080/z-a.2021.108.047

\title{
Identification and functional prediction of long non-coding RNAs responsive to heat stress in heading type Chinese cabbage
}

\author{
Seung Hee EOM ${ }^{1}$, Hee Ju LEE², Seung Hwan $\mathrm{WI}^{2}$, Sung Kyeom KIM ${ }^{3}$, Tae Kyung HYUN ${ }^{1}$ \\ ${ }^{1}$ Chungbuk National University, Department of Industrial Plant Science and Technology \\ Cheongju 28644, Republic of Korea \\ E-mail: taekyung7708@chungbuk.ac.kr \\ ${ }^{2}$ National Institute of Horticultural and Herbal Science, Vegetable Research Division \\ Wanju 55365, Republic of Korea
}

${ }^{3}$ Kyungpook National University, Department of Horticultural Science

Daegu 41566, Republic of Korea

\begin{abstract}
Global warming is a devastating force that considerably hinders the growth, quality and yield of heading type Chinese cabbage (Brassica rapa L. ssp. pekinensis). Recent research suggests that long non-coding ribonucleic acids (lncRNAs) play a role in response to abiotic and biotic stresses. In this study, a total of 278 lncRNAs belonging to intergenic, intronic, sense and natural antisense lncRNAs in the heading type Chinese cabbage using RNA-sequencing (RNA-seq) data were identified. Based on the analysis of the differentially expressed lncRNAs, 93 out of 278 lncRNAs were identified as heat-responsive lncRNAs. In total, 65 heat-responsive lncRNAs were predicted as putative targets and target mimics of B. rapa microRNAs (miRNAs). In addition, it was found that some identified lncRNAs play important role in response to heat stress via lncRNA-messenger RNA (mRNA) (lncRNA.Brassica 094-DnaJ protein and lncRNA.Brassica 181-REF4-related 1) co-expression, whereas some IncRNA-miRNA (IncRNA-Brassica_116-bra-miR164a and lncRNA-Brassica_205-bra-miR159) interactions are required for modulation of miRNA action.

Taken together, these results provide the starting point for a detailed investigation of the physiological function of the IncRNA-dependent network in heading type Chinese cabbage.
\end{abstract}

Key words: Brassica rapa ssp. pekinensis, epigenetic regulator, heat stress, long non-coding RNA, RNA-seq.

\section{Introduction}

Increased fossil fuel usage and the release of greenhouse gasses into the atmosphere shape the future of Earth's climate as global temperatures continue to rise. Based on global climate model analysis, it has been suggested that heat stress will cause billions of dollars in losses of agricultural crops worldwide and food security (Sun et al., 2019). For example, it has been found that heat stress causes a decrease in national wheat production by more than $6 \%$ for each degree increase in temperature (Asseng et al., 2015). In addition, high temperatures lead to rising rates of fruit abortion and disruption of seed production in Brassica napus (Young et al., 2004), and heat stress during grain filling significantly reduced starch accumulation in maize (Yang et al., 2018), rice (Yamakawa, Hakata, 2010) and wheat (Hurkman et al., 2003). Under conditions of heat stress, crops exhibit various physiological and biochemical responses such as alterations in plant growth, development, yield and biosynthetic and antioxidant pathways (Hasanuzzaman et al., 2013).
Since the physiological and molecular responses to heat stress have become a major subject in crop science, it has been found that the transcriptional reprogramming of genes is necessary to provoke a heat-stress response (Kong et al., 2020). For example, acetylation levels of histone H3K9 and H3K14 at the promoters of Arabidopsis heat shock transcription factor A3 correlate with their activation under heat stress conditions (Hu et al., 2015). In Arabidopsis, a null mutant for NRPD2, the secondlargest subunit of RNA polymerases IV and V complexes, caused the misexpression of genes harbouring RNAdirected DNA methylation (RdDM) target sequences resulting in reduced heat resistance (Popova et al., 2013). These findings indicate that epigenetic regulation of stress-induced transcriptional reprogramming plays an important role in plant stress tolerance.

Among the epigenetic regulators, transcriptional and post-transcriptional regulation by long non-coding ribonucleic acids (lncRNAs) have recently started to be recognized, and the accumulated evidence from model-

Please use the following format when citing the article:

Eom S. H., Lee H. J., Wi S. H., Kim S. K., Hyun T. K. 2021. Identification and functional prediction of long non-coding RNAs responsive to heat stress in heading type Chinese cabbage. Zemdirbyste-Agriculture, 108 (4): 371-376. DOI 10.13080/z-a.2021.108.047 
plant systems revealed that lncRNAs play critical roles in plant stress responses by targeting stress-response messenger RNAs (mRNAs), transcription factors and microRNAs (miRNAs) (Sun et al., 2018; Jha et al., 2020; Waititu et al., 2020). Under heat stress conditions, several lncRNAs were identified as precursors of miRNAs and siRNAs (Yao et al., 2010; Xin et al., 2011). In addition, Arabidopsis lnc-173 and its target gene sucrose synthase 4 share opposite transcription patterns in response to heat stress (Di et al., 2014) indicating that some lncRNAs also act as transcriptional repressors of target genes. Although our understanding of the role of lncRNAs in plant response against heat stress is extremely limited, the identification and functional prediction of heat stressresponsive lncRNAs in various plants should provide the opportunity to understand epigenetic regulation during the heat stress response and to identify the potential candidates for improving plant tolerance.

In this study, heat-responsive lncRNAs from heading type Chinese cabbage (Brassica rapa L. ssp. pekinensis), an important leafy vegetable grown worldwide, were identified using high-throughput RNA-seq data combined with a bioinformatic approach. In addition, miRNAs and genes that could potentially interact with the identified heat-responsive lncRNAs was analysed and suggested that the identified IncRNAs could potentially provide new insights into the plant response to heat stress.

\section{Materials and methods}

Plant growth and heat stress treatment. The experiment was carried out in 2020 at the National Institute of Horticultural and Herbal Science, Republic of Korea. Heading type Chinese cabbage (Brassica rapa L. ssp. pekinensis) seeds were sown and grown in a glasshouse. Forty days after transplanting the seedlings, the plants were transferred to environmental growth chambers and modified CEEWS model (Chagrin Falls, USA) with optimal lighting conditions at $20 / 16^{\circ} \mathrm{C} 14 / 10 \mathrm{~h}$ light/night. For the heat treatment, the plants were shifted from $20 / 16^{\circ} \mathrm{C}$ to $36 / 32^{\circ} \mathrm{C}$ for 8 days. For total ribonucleic acid (RNA) isolation, the leaf blades were collected from whole leaves excluding the midrib. The experiment was conducted with three replicates and five plants per replicate.

Identification of heat-responsive long noncoding ribonucleic acids (lncRNAs). RNA-sequencing (RNA-seq) data from non-treated $\left(30 / 16^{\circ} \mathrm{C}\right.$ day/night for 8 days) and heat-treated $\left(36 / 32^{\circ} \mathrm{C}\right.$ day/night for 8 days) samples, accession Nos. NN-6790 and NN6791 were obtained from the National Agricultural Biotechnology Information Center, Republic of Korea. lncRNAs were predicted and identified as described by
Eom et al. (2019) with modification. Firstly, transcripts with lengths longer than 200 nucleotides (nt) were considered as lncRNA candidates. The protein coding sequences were then removed from the sample using BLASX against Pfam and Swiss-Prot databases (E value $<10^{-5}$ ). Then, the coding potential of the remaining transcripts was evaluated using a software Coding Potential Calculator (CPC score < 0) (Kong et al., 2007); further, housekeeping lncRNAs including ribosomal, transfer, small nuclear and small nucleolar RNAs were filtered out. After removing transcripts that completely matched with the $B$. rapa gene, the remaining transcripts were defined as lncRNAs. IncRNAs were mapped to the B. rapa reference sequence (BrapaV2.1). Transcript levels and relative transcript abundances were analysed, and the differentially expressed lncRNAs (DELs) were determined by combining $p$ value cut-off of 0.01 and adjusting to $\mid \log 2$ (fold change) $\mid \geq 1$.

Functional analysis of heat-responsive lncRNAs. To explore whether lncRNAs function as candidate endogenous target mimics for microRNAs (miRNAs), all identified lncRNAs were submitted to psRNATarget (https://plantgrn.noble.org/psRNATarget/analysis) with the default parameters (maximum expectation $=5$ and allowed maximum energy to unpair the target site $=25$ ).

As described by Eom et al. (2019), the coding genes located $100 \mathrm{~kb}$ upstream and downstream of all identified lncRNAs were predicted as cis-regulation target genes of heat-responsive lncRNAs. These predicted target genes were functionally annotated using gene ontology (GO) (http://geneontology.org/).

Expression analysis using quantitative real-time PCR (qRT-PCR). Total RNA extraction and complementary DNA (cDNA) synthesis for the expression analysis of selected miRNAs were performed using TRIzol reagent (Invitrogen, USA) and the Mir-X miRNA First-Strand Synthesis kit (Clontech Takara). In order to analyse the expression of selected lncRNAs and target genes, total RNA extracted from the heattreated Chinese cabbage sample was reverse-transcribed into cDNA using the ReverTra Ace ${ }^{\circledR}$ qPCR RT Master Mix (Toyobo Co. Ltd., Japan). The expression level of each gene was normalized to the internal reference gene actin and then was expressed relative to its value for non-treated samples. miRNA-specific primers were designed according to the instructions provided by the manufacturer of Mir-X miRNA First-Strand Synthesis kit. In addition, primers for lncRNAs and target genes were designed using GenScript Real-time PCR Primer Design (https://www.genscript.com/tools/real-time-pcrtaqman-primer-design-tool). The specific primer pairs used for qRT-PCR are listed in Table 1.

Table 1. The primers of microRNAs (miRNAs), long non-coding RNAs (lncRNAs) and target genes used for qRT-PCR

\begin{tabular}{llll}
\hline \multicolumn{1}{c}{ Primer name } & \multicolumn{1}{c}{ Sequence $\left(5^{\prime} \rightarrow 3^{\prime}\right)$} & \multicolumn{1}{c}{ Primer name } & \multicolumn{1}{c}{ Sequence $\left(5^{\prime} \rightarrow 3^{\prime}\right)$} \\
\hline bra-miR156-5p & TGACAGAAGAGAGTGAGCAC & lncR.Brassica_094-F & TCGAAATCTCTCAACTTAGCAC \\
bra-miR159 & TTTGGATTGAAGGGAGCTCTA & lncR.Brassica_094-Rev & AGGAATCTCGACGATTGGTAG \\
bra-miR164 & TGGAGAAGCAGGGCACGTGCA & lncR.Brassica_181-F & TCTCATCCGGAGTGTTGAGT \\
lncR.Brassica_116-F & GCAACTGGAACCGCAAAAGAAC & lncR.Brassica_181-Rec & GGAAGGAAGGAATGGGTCGG \\
lncR.Brassica_116-Rev & CTGCATTCGCACACACATGAC & BraA03g059840-F & CGGGAACCGATCGGAGTAAC \\
lncR.Brassica_159-F & CCAAAATCATCTCCTCGCC & BraA03g059840-Rev & CCGATCGTAAACAGAGCGTT \\
lncR.Brassica_159-Rev & CGTCTTCGTCTGTCTTCCTC & BraA07g009510-F & CTTGCTCCAGGAGGGAGTTC \\
lncR.Brassica_205-F & GAAAGCAGCAAATCAGCAACCC & BraA07g009510-Rev & GCTACAATGGGCATGCAAGG \\
lncR.Brassica_205-Rev & CCGCTTCTTTCGTTCGTTTCCC & & \\
lncR.Brassica_194-F & TAACGCGGCAACCAGAGAGAAC & & \\
lncR.Brassica_194-Rev & TATGTGTCACCTTTCGCGGC & & \\
\hline
\end{tabular}

Statistical analysis. Statistical significance for differences between treatments was analysed using the unpaired Student's $t$-test; $* * * * *$ and $*$ indicate significance at $p<0.001, p<0.01$ and $p<0.05$, respectively.

\section{Results and discussion}

Identification of the long non-coding RNAs (IncRNAs) in heading type Chinese cabbage. To identify and investigate lncRNAs implicated in the response to 
heat stress, 49 million paired-end clean reads obtained from the non-treated and heat-treated Chinese cabbage RNA-seq library were mapped and assembled on to the reference $B$. rapa genome (http://brassicadb.org/brad/ datasets/pub/Genomes/Brassica rapa/V3.0/). From the total 101,145 assembled transcripts, $83.4 \%$ of transcripts were found to be messenger RNAs (mRNAs) after the application of a transcript length filter. After filtering the remaining transcripts using a filtering pipeline, 278 transcripts were identified as lncRNAs.

An analysis of the distribution on the chromosomes revealed that the identified lncRNAs are spread over all chromosomes and chromosomes A03 (39 lncRNAs) and A06 (38 lncRNAs) harbour relatively high numbers of lncRNAs (Figure 1A). In addition, the lengths of the identified lncRNAs ranged from 204 to $8,203 \mathrm{nt}$ with an average length of 1,139 nt (Figure 1B).
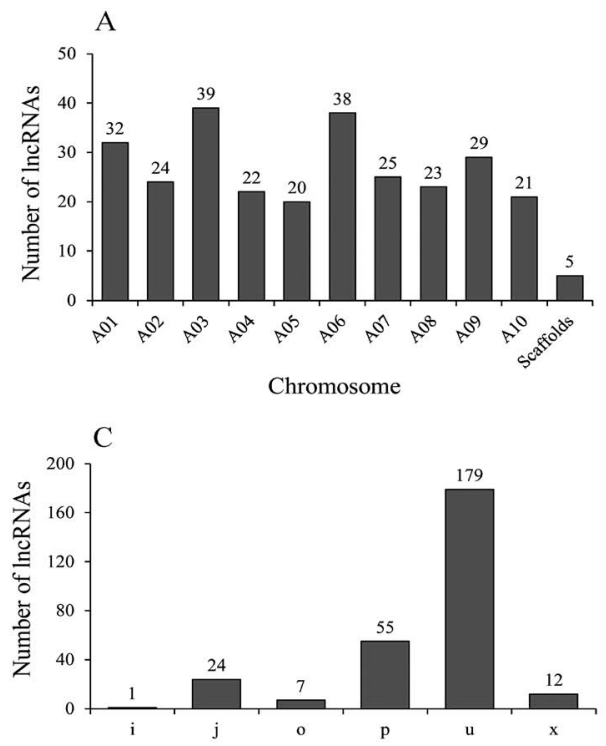

Based on the genetic location and orientation of the lncRNAs, they have been classified into intergenic, intronic, sense and natural antisense lncRNAs. As shown in Figure $1 \mathrm{C}$, the identified lncRNAs belong to six categories, which are further classified into four groups. The long intergenic lncRNAs (lincRNAs) including the ' $u$ ' (unknown intergenic transcript) and the 'p' (possible polymerase run-on fragment) classcodes represented the largest group (234 lncRNAs) followed by sense lncRNAs, including 24 lncRNAs with ' $\mathrm{j}$ ' and 7 lncRNAs with ' 0 '. Additionally, 12 lncRNAs and one lncRNA were assigned the ' $\mathrm{x}$ ' classcode of natural antisense lncRNAs and the 'I' classcode (intronic lncRNAs), respectively, suggesting that lincRNAs constituted the largest proportion of lncRNAs in lincRNAs accounted for the largest proportion.

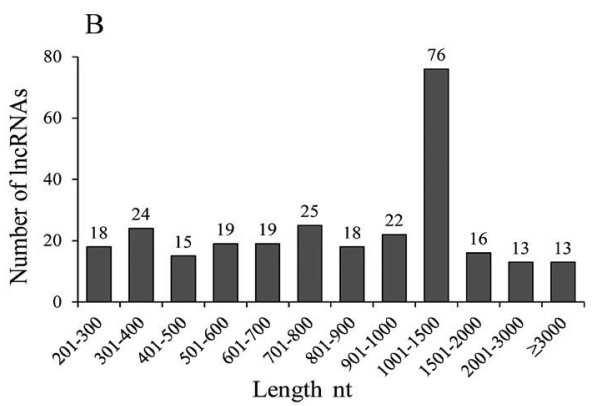

$\mathrm{i}-$ a transfrag falling entirely within a reference intron
$\mathrm{j}-$ potentially novel isoform (fragment): at least one
splice junction is shared with a reference transcript
$\mathrm{o}-$ generic exonic overlap with a reference transcript
$\mathrm{p}-$ possible polymerase run-on fragment (within $2 \mathrm{~K}$
$\quad$ bases of a reference transcript)
$\mathrm{u}-$ unknown intergenic transcript
$\mathrm{x}-$ exonic overlap with reference on the opposite strand

Figure 1. Features of heat-responsive long non-coding RNAs (lncRNAs) in Chinese cabbage: chromosome (A) and length (B) distribution and categories of lncRNAs (C)

Owing to low expression levels and low conservation of lincRNA sequences between species, lincRNAs were regarded as transcription noise (Struhl, 2007). However, mounting evidence suggests that lincRNAs possess diverse features including modifications of target mRNA splicing and transcriptional regulation, remodelling chromatin and RNA stabilization via interaction with RNA binding proteins in animals and plants (Ma et al., 2014; Deforges et al., 2019; Fukuda et al., 2019; Rai et al., 2019). For example, auxin regulated Promoter Loop RNA (APOLO) transcribed by RNA Pol II/Pol V induces the gene silencing of PINOID (regulator of polar auxin transport) in Arabidopsis (Ariel et al., 2014). Another plant lincRNA is ELENA1 (ELF18Induced Long Noncoding RNA 1) that enhances plant resistance against Pseudomonas syringae through the modulation of PR1 (pathogenesis-related 1) levels (Seo et al., 2017). Although the physiological function of heatresponsive lincRNAs is still unclear, it can be hypothesized that some heat-responsive lincRNAs are thought to serve as transcriptional regulators of heat-responsive genes.

Heat-responsive IncRNAs as potential miRNA targets. To identify heat-responsive lncRNAs, differentially expressed lncRNAs (DELs) were analysed in the nontreated and heat-treated samples. In heat-treated samples, 50 lncRNAs (e.g., lncR.Brassica 033, lncR.Brassica 194 and IncR.Brassica 205) were highly expressed, whereas the expression of 43 lncRNAs (e.g., lncR.Brassica 94, lncR.Brassica_116, IncR.Brassica_159 and lncR.Brassica 185) was down-regulated by heat treatment.
As described above, lncRNAs not only control gene expression at the mRNA level but also play a role as functional endogenous miRNA target mimics and potential miRNA precursors (Yamada, 2017; Narnoliya et al., 2019) suggesting that the identification of interactions between lncRNAs and miRNAs is important for understanding the physiological functions of novel lncRNAs. In this study, 65 heat-responsive lncRNAs were predicted to be putative targets of B. rapa 93 miRNAs. As shown in Table 2, lncR. Brassica 116 interacted with 9 miRNAs, whereas $\operatorname{lncR}$. Brassica 033 was found to bind to bra-miR1583-3p.

In Arabidopsis, miR156s play an important role for various biological processes including leaf development, flowering, fruit ripening, fertility, biomass production and response to stresses (Huijser, Schmid, 2011; Wang, Wang, 2015). In addition, miR156-overexpressing plants reduce the expression of SPL transcription factor 2, 9 and 11 and promote the expression of heat stress-responsive genes resulting in enhanced heat tolerance (Stief et al., 2014).

In wheat, heat shock protein HSP17 is a direct target of miR164 under heat stress conditions (Kumar et al., 2015). Furthermore, miR159 is downregulated by heat stress leading to the accumulation of GAMYB transcription factorgenes, which are involved in gibberellic acid signalling and flower development (Wang et al., 2012; Ding et al., 2020). In rice, miR159-overexpressing plants exhibited a more sensitive phenotype against heat stress (Wang et al., 2012; Ding et al., 2020). Although the physiological functions of lncRNA-miRNA-mRNA networks under heat stress conditions are not fully 
Table 2. List of microRNAs (miRNAs) targeting the heat-responsive Chinese cabbage long non-coding RNAs (lncRNAs)

\begin{tabular}{|c|c|c|c|}
\hline lncRNA ID & miRNA ID & lncRNA aligned fragment & Inhibition \\
\hline lncR.Brassica 033 & bra-miR158-3p & UCUUUUCUAUAUAUUUGGAGU & cleavage \\
\hline \multirow{9}{*}{ lncR.Brassica_116 } & bra-miR9408-3p & UCGAGUGUUCUCUAAGAUGGAU & cleavage \\
\hline & bra-miR400-3p & CCCAUGAUGGUCAUUAUGAGUU & cleavage \\
\hline & bra-miR164a & GUCACGGUACCUGCUUCUCUU & cleavage \\
\hline & bra-miR164b-5p & GUCACGGUACCUGCUUCUCUU & cleavage \\
\hline & bra-miR $164 c-5 p$ & GUCACGGUACCUGCUUCUCUU & cleavage \\
\hline & bra-miR $164 d-5 p$ & GUCACGGUACCUGCUUCUCUU & cleavage \\
\hline & bra-miR164e-5p & AGUCACGGUACCUGCUUCUCUU & cleavage \\
\hline & bra-miR403-3p & UCAAUAUGUCCGUGAGUUUGA & cleavage \\
\hline & bra-miR5720 & UCUAUUCCAAGCAAA-CGCAA & translation \\
\hline \multirow{8}{*}{ lncR.Brassica_159 } & bra-miR398-5p & CUUCUGUUUUCAUGUUGUUUC & cleavage \\
\hline & bra-miR $156 a-5 p$ & GUUUUCUUUUUCUUCUGUUU & cleavage \\
\hline & bra-miR156b-5p & GUUUUCUUUUUCUUCUGUUU & cleavage \\
\hline & bra-miR $156 c-5 p$ & GUUUUCUUUUUCUUCUGUUU & cleavage \\
\hline & bra-miR $156 d-5 p$ & GUUUUCUUUUUCUUCUGUUU & cleavage \\
\hline & bra-miR $156 \mathrm{e}-5 \mathrm{p}$ & GUUUUCUUUUUCUUCUGUUU & cleavage \\
\hline & bra-miR156f-5p & GUUUUCUUUUUCUUCUGUUU & cleavage \\
\hline & bra-miR $156 g-5 p$ & GUUUUCUUUUUCUUCUGUUU & cleavage \\
\hline \multirow{2}{*}{ lncR.Brassica_194 } & bra-miR159a & UUGAGCAUCUAUCGAUUCAAA & translation \\
\hline & bra-miR5722 & GCAUACACAUGAUUCCAUCUUA & cleavage \\
\hline
\end{tabular}

understood, these findings suggest that heat-responsive lncRNAs, which are miRNA target mimics or precursors of miRNAs, are necessary to the heat stress response.

In order to evaluate the relationship between miRNAs and their target lncRNAs, the expression patterns of miR156, miR159 and miR164 were compared with their target lncRNAs. As shown in Figure 2, bramiR164a was up-regulated by heat stress, whereas its target lncRNA-Brassica 116 was reduced. In addition, bra-miR156a-5p and bra-miR159a were down-regulated, whereas IncRNA-Brassica 194 and IncRNA-Brassica 205 were induced by heat stress. In humans, miRNA $\bar{s}$ can regulate the expression of lncRNAs through DNA methylation and degrade lncRNAs in an AGO-dependent manner, whereas lncRNAs can inhibit the expression of miRNAs via the sponging effect (Sun et al., 2020).

This negative relationship indicates that these miRNAs and lncRNAs constitute a negative feedback loop. Furthermore, IncRNA-Brassica_159 and bra-
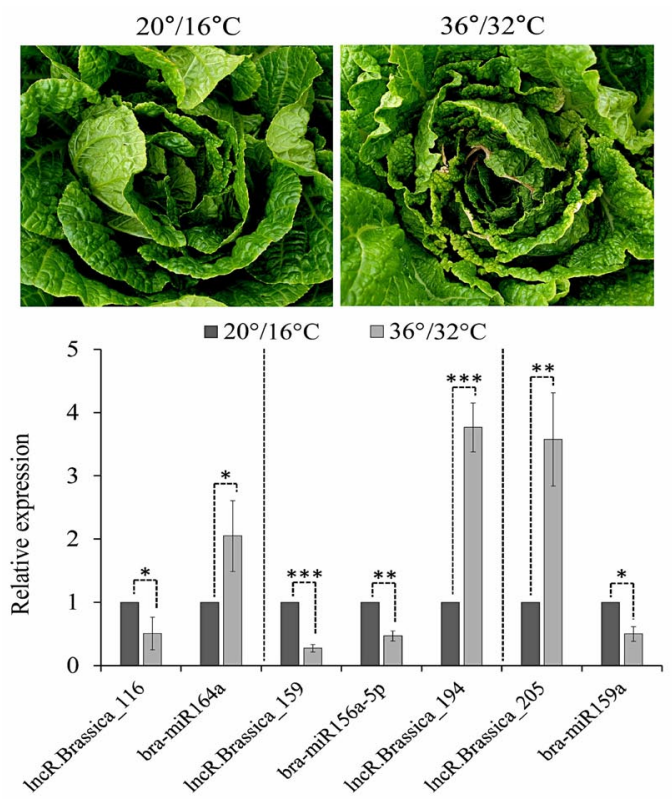

Note. The transcription levels of selected lncRNAs and miRNAs were analysed relative to their expression in the nontreated sample $\left(20 / 16^{\circ} \mathrm{C}\right)$; each value represents the mean $\pm \mathrm{SE}$ of triplicate measurements; $* * *, * *$ and $*-$ significant at $p<$ $0.001, p<0.01$ and $p<0.05$.

Figure 2. Expression analysis of heat-responsive long non-coding RNAs (lncRNAs) as potential targets or target mimics of microRNAs (miRNAs)
miR156a-5p exhibited the same expression pattern (Figure 3) indicating that lncRNA-Brassica_159 may operate as a target mimic of bra-miR $156 a-5 p$ under heat stress conditions, as described by Eom et al. (2019). Taken together, these findings suggest that our identified lncRNAs can interact with miRNA to inhibit miRNA action and, furthermore, indicate that IncRNABrassica_205 might be a good candidate for improving heat tolerance via inhibition of miR159 expression.

Functional annotation of IncRNA target genes. Since lncRNAs play an important role in regulating the expression of their neighbouring genes as the cis-acting role of IncRNAs, it has been suggested that identifying their target genes could help to elucidate their functions (Wang et al., 2018). To identify the cis-regulation target genes of lncRNAs, the locations of all identified lncRNAs and genes were analysed. Overall, 33 genes were predicted as targets of heat-responsive lncRNAs and classified according to gene ontology (GO) terms.

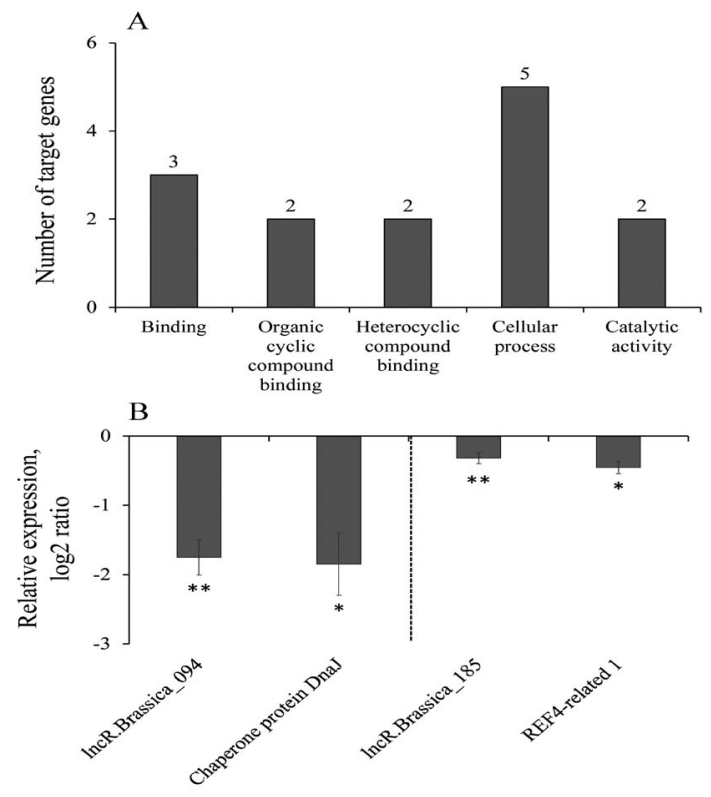

Note. Number of heat-responsive lncRNA target genes assigned to each gene ontology term (A); expression levels of the selected IncRNA-mRNA pairs from heat-treated samples were compared to a non-treated sample (B); level of expression is represented by $\log 2$ ratio; $* *$ and $*$ - significant at $p<0.01$ and $p<0.05$.

Figure 3. Functional category and expression analysis of selected long non-coding RNAs and microRNAs (lncRNAs-miRNAs) 
As shown in Figure 3A, five genes were classified into the group of "cellular process", whereas two genes were aligned to "heterocyclic compound binding", "organic cyclic compound binding" and "catalytic activity". This suggests that some lncRNAs contribute to heat stress response via modulation of target genes involved in biological processes including "cellular process".

To investigate the relationship between heatresponsive lncRNAs and their target genes, two lncRNA and target gene pairs were selected, and their transcription patterns were analysed in response to heat stress. DnaJ proteins, also referred to as heat shock proteins (Hsp40), are known as co-chaperones involved in abiotic and biotic stress responses via interaction with Hsp70 (Salas-Muñoz et al., 2016). In tomato plants, DnaJ20-overexpression in the plant resulted in enhanced heat tolerance by promoting the expression of heat stress transcriptional factors (Wang et al., 2019) suggesting that DnaJ proteins play an essential role in response to heat stress.

In heading type Chinese cabbage, lncRNA. Brassica 094 and its potential target gene, chaperone protein DnaJ (BraA03g059840.3C), were down-regulated (Figure 3B). Similarly, lncRNA.Brassica 185 and its target gene REF4-related 1 (mediator of RNA $\bar{A}$ polymerase II transcription subunit 33A, BraA07g009510.3C) exhibited the same transcription patterns in response to heat stress. In higher plants, loss of function mutant ref4-related 1 exhibited the hyperaccumulation of phenylpropanoids (Bonawitz et al., 2012).

In addition, exogenous application of phenylpropanoids improved heat stress tolerance via reactive oxygen species (ROS), unrelated microfilament protection mechanisms and ROS detoxification (Commisso et al., 2016). These indicate that downregulation of Chinese cabbage gene REF4-related 1 (Figure 3B) is necessary for phenylpropanoid homeostasis under heat stress conditions. Taken together, they share similar transcription patterns between IncRNAs, and their target genes suggest that they are transcriptionally co-regulated indicating some heatresponsive IncRNAs function as transcriptional regulators of heat responses in heading type Chinese cabbage.

\section{Conclusions}

1. Among 278 long non-coding RNAs (lncRNAs) in heading type Chinese cabbage, 93 heatresponsive lncRNAs were identified.

2. The analysis of long non-coding RNAs and microRNAs (lncRNA-miRNA) and lncRNA-messenger RNA (mRNA) interactions indicates that the identified lncRNAs are involved in heat stress response.

3. Some lncRNAs including lncRNA-Brassica 205, lncRNA.Brassica 094 and lncRNA.Brassica $18 \overline{5}$ might have important application value for improving heat tolerance, although further investigation of these lncRNAs-mediated mechanisms is required.

4. Unravelling lncRNA-dependent networks should be an interesting challenge, one in need of greater knowledge about crop responses to global climate change.

\section{Acknowledgements}

This work was carried out with the support of project "Cooperative Research Program for Agriculture Science and Technology Development" (No.PJ01501905) Rural Development Administration, Republic of Korea.

Received 05012021 Accepted 04062021

\section{References}

Asseng S., Ewert F., Martre P. et al. 2015. Rising temperatures reduce global wheat production. Nature Climate Change, 5: 143-147. https://do1.org/10.1038/nclimate2470

Ariel F., Jegu T., Latrasse $\bar{D}$., Komero-Barrios $\bar{N}$., Christ A. Benhamed M., Crespi M. 2014. Noncoding transcription by alternative RNA polymerases dynamically regulates an auxin-driven chromatin loop. Molecular Ce11, 55 (3) 383-396. https://doi.org/10.1016/j.molcel.2014.06.011
Bonawitz N. D., Soltau W. L., Blatchley M. R., Powers B. L., Hurlock A. K., Seals L. A., Weng J.-K., Stout J., Chapple C. 2012. REF4 and RFR1, subunits of the transcriptional coregulatory complex mediator, are required for phenylpropanoid homeostasis in Arabidopsis. The Journal of Rinlogical Chemistry 287 (8): 5434-5445.

https://doi.org/10.1074/jbc.M111.312298

Commisso M., Iotfali K., strazzer P., Stocchero M. Ceoldo S., Baldan B., Levi M., Guzzo F. 2016. Impact of phenylpropanoid compounds on heat stress tolerance in carrot cell cultures. Frontiers in Plant Science, 7: 1439 https://doi.org/10.3389/fpls.2016.01439

Deforges $\bar{J}$., Keis $\bar{K}$. S.., Jacquet $\overline{\text {. }}$., Vuarambon D. J., Poirier Y. 2019. Prediction of regulatory long intergenic non-coding RNAs acting in trans through base-pairing interactions. BMC Genomics, 20: 601 https://doi.org/10.1186/s12864-019-5946-0

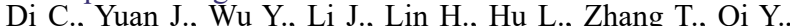
Gerstein M. B., Guo Y., Lu Z. J. 2014. Characterization of stress-responsive lncRNAs in Arabidopsis thaliana by integrating expression, epigenetic and structural features. The Plant Journal, 80 (5): 848-861. https://doi.org/10.1111/tpj. 12679

Ding Y., Huang $\bar{L}$., Jiang Q., Zhu C. 2020. MicroRNAs as important regulators of heat stress responses in plants. Journal of Agricultural and Fond Chemistry 68 (41): 11320-11326. https://doi.org/10.1021/acs.jafc.0c03597

Eom S. H., Lee H. J., Lee J. H., Wi S. H., Kim S. K., Hyun I. K. 2019. Identification and functional prediction of droughtresponsive long non-coding RNA in tomato. A gronomy, 9 (10): 629. https://doi.org/10.3390/agronomy9100629

Fukuda M., Nishida S., Kakei Y., Śnimada Y., Fujiwara T. 2019. Genome-wide analysis of long intergenic noncoding RNAs responding to low-nutrient conditions in Arabidopsis thaliana: possible involvement of trans-acting siRNA3 in response to low nitrogen. Plant and Cell Physiology, 60 (9): 1961-1973. https://doi.org/10.1093/pcp/pcz048

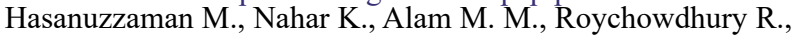
Fujita M. 2013. Physiological, biochemical, and molecular mechanisms of heat stress tolerance in plants. International Iournal of Molecular Sciences, 14 (5): 9643-9684. https://doi.org/10.3390/ijms14059643

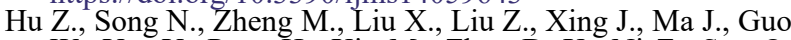
W., Yao Y., Peng H., Xin M., Zhou D.-X., Ni Z., Sun Q. 2015. Histone acetyltransferase GCN5 is essential for heat stress-responsive gene activation and thermotolerance in Arabidonsis. The Plant Iournal, 84 (6): 1178-1191. https://doi.org/10.1111/tpj.13076

Huijser $\bar{P}$. Schmid $\bar{M}$. Zuil. The control of developmental phase transitions in plants. Develonment, 138 (19): 4117 4129. https://doi.org $/ 10.1242 /$ dev.063511

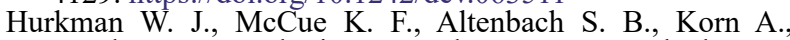
Tanaka C. K., Kothari K. M., Johnson E. L., Bechtel D. B., Wilson J. D., Anderson O. D., DuPont F. M. 2003. Effect of temperature on expression of genes encoding enzymes for starch biosynthesis in developing wheat endosperm. Plant Srience 164 (5) $873-881$

https://doi.org/10.1016/S0168-9452(03)00076-1

Jha U. C., Nayyar H., Jha K., Khurshid M., Zhou M., Mantri N., Siddique K. H. M. 2020. Long non-coding RNAs: emerging players regulating plant abiotic stress response and adaptation. BMC Plant Biology, 20: 466. https://doi.org/10.1186/s12870-020-02595-x

Kong L., Zhang Y., Ye Z. Z.-Q., Liu X.-Q̄., Zhao S.-Q., Wei L., Gao G. 2007. CPC: assess the protein-coding potential of transcripts using sequence features and support vector machine. Nucleic Acids Research, 35 (2): W345-349. https://doi.org/10.1093/nar/gkm391

Kong L., Liu Y., Wang X., Chang C. Z ZU20. Insight into the role of epigenetic processes in abiotic and biotic stress response in wheat and barley. International Journal of Molecular Sciences, $21(4) \cdot 1480$ https://doi.org/10.3390/ijms21041480

Kumar K. K., Yrathak $\bar{H}$., Sharma S. K., Kale Y. K., Nirjal M. K. Singh G. P., Goswami S., Rai R. D. 2015. Novel and conserved heat-responsive microRNAs in wheat (Triticum aestivum L.). Functional and Inteorative Fenomics 15 (3): 323-348. https://doi.org/10.1007/s10142-014-0421-0

Ma X., Shao C., Jin Y., Wang H., Meng Y. 2014. Long noncoding RNAs: a novel endogenous source for the generation of Dicer-like 1-dependent small RNAs in Arabidopsis thaligng. RNI B Biologv 11 (4): 373-390. https://doi.org/10.4161/rna.28725

Narnoliya L. Ǩ., Kaushai Ğ., Singh S. P. 2019. Long noncoding RNÂs and miRNAs regulating terpene and tartaric acid biosynthesis in rose-scented geranium. FFRS I etters, 593 (16): 2235-2249. https://doi.org/10.1002/1873-3468.13493 
Popova O. V., Dinh H. Q., Aufsatz W., Jonak C. 2013. The RdDM pathway is required for basal heat tolerance in Arahidonsis. Molecular Plant, 6 (2): 396-410. https://doi.org/10.1093/mp/sst023

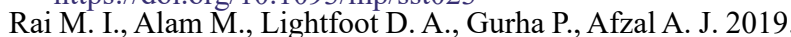
Classification and experimental identification of plant long non-coding RNAs. Genomics, 111 (5): 997-1005. https://doi.org/10.1016/j.ygeno.2018.04.014

Salas-Miunoz S., Kodriguez-Hernandez A. A., OrtegaAmaro M. A., Salazar-Badillo F. B., Jiménez-Bremont J. F. 2016. Arabidopsis AtDjA3 null mutant shows increased sensitivity to abscisic acid, salt, and osmotic stress in germination and nost-germination stages. Frontiers in P!ant Science, 7: 220. https://doi.org/10.3389/fpls.2016.00220

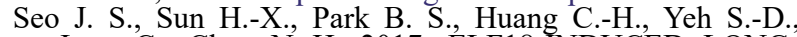
Jung C., Chua N.-H. 2017. ELF18-INNDUCED LONGNONCODING RNA associates with mediator to enhance expression of innate immune response genes in Arabidopsis. The Plant Ce11 20 (5). 1024-1038. https://doi.org/10.1105/tpc.16.00886

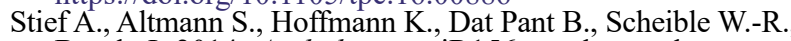
Bäurle I. 2014. Arabidopsis miR156 regulates tolerance to recurring environmental stress through SPL transcription factors. The Plant Cel1, 26 (4): 1792-1807. https://doi.org/10.1105/tpc.114.123851

Struhi $\overline{\mathrm{K}} \cdot \overline{2} \bar{U} \overline{\%}$. Transcriptionai noise and the fidelity of initiation by RNA polymerase II. Nature Structural and Molecular Biology, 14 (2): 103-105. https://doi.org/10.1038/nsmb0207-103

Sun X., Zheng $\bar{H}$., Sui N. Z̃uiz. Kegulation mechanism of long non-coding RNA in plant response to stress. Biochemical and Biophysical Research Communications, 503 (2): 402407. https://doi.org/10.1016/j.bbrc.2018.07.072

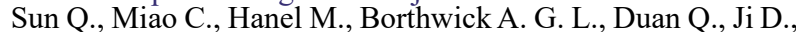
Li H. 2019. Global heat stress on health, wildfires, and agricultural crops under different levels of climate warming. Environment International, 128: 125-136. https://doi.org/10.1016/j.envint.2019.04.025

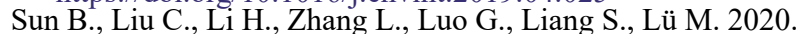
Research progress on the interactions between long noncoding RNAs and microRNAs in human cancer (review). Oncolony Ietters, 10 (1): 505-605. https://doi.org/10.3892/ol.2019.11182

Waititu J. K., Zhang C., Liu J., Wang H. 2020. Plant non-coding RNAs: origin, biogenesis, mode of action and their roles in abiotic stress. International Inurnal of Mnlecular Sciences, 21 (21): 8401. https://doi.org/10.3390/ijms21218401
Wang H., Wang H. 2015. The miR156/SPL module, a regulatory hub and versatile toolbox, gears up crops for enhanced agronomic traits. Molecular Plant, 8 (5): 677-688. https://doi.org/10.1016/j.molp.2015.01.008

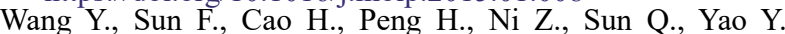
2012. TamiR159 directed wheat TaGAMYB cleavage and its involvement in anther development and heat response. PI QS ONE, 7 (11): e48445. https://doi.org/10.1371/journal.pone.0048445

Wang L., Xia X. Jiang $\bar{H}$., Lu $\bar{Z}$., Cui $\bar{J}$., Cao $\overline{\mathrm{H}}$, Jin B. 2018. Genome-wide identification and characterization of novel lncRNAs in Ginkon hilnho. Trees, 32: 1420-1442. https://doi.org/10.1007/s00468-018-1724-x

Wang G., Cai G., Xu Ñ., Zhang L., Sun XX., Guan J., Meng Q. 2019. Novel DnaJ protein facilitates thermotolerance of transgenic tomatoes. International Inurnal of Molecular Sciences, 20(2): 367. https://doi.org/10.3390/ijms20020367

Xin $M$. Wang $Y$, Yao $\bar{Y}$, Song $\bar{N}$, $\bar{H}$ U $\bar{Z}$, Uin $\bar{D}$, Xie $\bar{C}$., Peng H., Ni Z., Sun Q. 2011. Identification and characterization of wheat long non-protein coding RNAs responsive to powdery mildew infection and heat stress by using microarray analysis and SBS seguencing. BMC Plant Biology, 11: 61. https://doi.org/10.1186/1471-2229-11-61

Yamada M. 2017. Functions of long intergenic non-coding (linc) RNI s in plants. Inurnal of Plant Recearch, 130 (1): 67-73. https://doi.org/10.1007/s10265-016-0894-0

Yamakawa H., Hakata M. 2UIU. Atias of rice grain fillingrelated metabolism under high temperature: joint analysis of metabolome and transcriptome demonstrated inhibition of starch accumulation and induction of amino acid accumulation. Plant and Cell Phvsiology, 51 (5): 795-809. https://doi.org/10.1093/pcp/pcq034

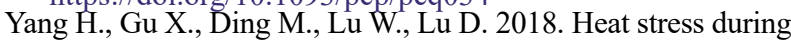
grain filling affects activities of enzymes involved in grain protein and starch synthesis in wavy maize. Scientific Reports, 8: 15665. https://doi.org/10.1038/s41598-018-33644-Z

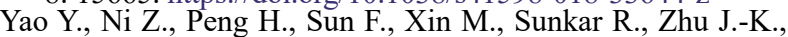
Sun Q. 2010. Non-coding small RNAs responsive to abiotic stress in wheat (Triticum aestivum L.). Functional and Integrative Genomics, 10 (2): 187-100. https://doi.org/10.1007/s10142-010-0163-6

Young L. W., Wilen K. W., Bonham-Smith P. C. 2004. High temperature stress of Brassica napus during flowering reduces micro- and megagametophyte fertility, induces fruit abortion and disrupts seed production. Journal of Exnerimental Rotany 55 (396): 485-495. https://doi.org/10.1093/jxb/erh038

\title{
Ilgų nekoduojančių RNR, reaguojančių ị karščio stresą, identifikavimas ir funkcinis numatymas kininiuose gūžiniuose kopūstuose
}

\author{
S. H. Eom ${ }^{1}$, H. J. Lee ${ }^{2}$, S. H. Wi' , S. K. Kim³ , T. K. Hyun ${ }^{1}$ \\ ${ }^{1}$ Chungbuko nacionalinio universiteto Pramoninių augalų mokslo ir technologijų katedra, \\ Korejjos Respublika \\ ${ }^{2}$ Nacionalinio sodininkystės ir daržininkystès instituto Daržovių tyrimų skyrius, \\ Korejos Respublika \\ ${ }^{3}$ Kyungpook nacionalinio universiteto Sodininkystės ir daržininkystės mokslų katedra, \\ Korèjos Respublika
}

\section{Santrauka}

Pasaulinis atšilimas daro įtaką gūžiniu kininiu kopūstų (Brassica rapa L. ssp. pekinensis) augimui, kokybei ir derliui. Naujausių tyrimų duomenys rodo, kad reaguojant $\mathfrak{i}$ abiotinị ir biotinị stresą didelès ịtakos turi ilgosios nekoduojančios ribonukleorūgštys (inRNR). Tyrimo metu panaudojus RNR sekoskaitos duomenis, kininiuose kopūstuose iš viso nustatytos 278 inRNR sekos, priklausančios tarpgeninėms, introninèms, tiesioginèms ir atvirkštinėms inRNR. Atlikus skirtingai išreikštu inRNR analize, 93 iš 278 inRNR buvo identifikuotos kaip i karštị reaguojančios inRNR. Iš viso 65 ị šilumą reaguojančios inRNR buvo numatytos kaip galimi Brassica rapa mikroRNR (miRNR) taikiniai ir taikiniu imitatoriai. Be to, nustatyta, kad kai kurios identifikuotos inRNR yra reikšmingos reaguojant i šilumos stresą per inRNR-mRNR (inRNA.Brassica_094-DnaJ baltymas ir inRNA. Brassica 181-REF4-related 1) bendrą raišką, o kai kurių inRNR-miRNR (inRNA-Brassica_116-bra-miR164a ir inRNA-Brassica_205-bra-miR159) sąveika yra būtina siekiant moduliuoti miRNR poveikį.

Apibendrinant tyrimo rezultatus galima teigti, kad jie yra pradinis taškas siekiant išsamiai ištirti nuo inRNR priklausomo tinklo fiziologinę funkciją kininiuose kopūstuose.

Reikšminiai žodžiai: kininiai kopūstai, epigenetinis reguliatorius, karščio stresas, ilgoji nekoduojanti RNR, RNRsekoskaita. 